\title{
OBTAINING STRAIN-PRODUCER OF RECOMBINANT HEXON OF BOVINE ADENOVIRUS TYPE 3
}

\author{
Mukantayev K.N., Tursunov K.A., Kanayev D.B., Tokhtarova L., \\ Ramankulov Ye. M., Mukanov K. K. \\ National center for biotechnology \\ Korgalzhyn road, 13/5, Astana, 010000, Kazakhstan \\ kanat tka@mail.ru
}

\section{ABSTRACT}

The diagnosis of bovine adenovirus is difficult due to a large number and identity of clinical symptoms with various diseases. For the diagnosis of adenoviral infection using various methods such as the isolation of the virus, in situ hybridization, enzyme-linked immunosorbent assay (ELISA), immunofluorescence, restriction analysis and polymerase chain reaction (PCR). The methods used are time consuming and require expensive equipment. In this regard, obtaining recombinant virus antigens of diagnostic importance is very important. One of the important diagnostic antigens is hexon, a group-specific protein that induces the formation of group-specific antibodies.

Under de novo conditions, the gene of the N-terminal fragment of hexon of BAV-3 with a length 503 base pairs was synthesized. A strain of E. coli BL21/pET28/rhAdv3 producing recombinant hexon of BAV-3 (rhAdv3) was obtained. The protein produced by the strain BL21/pET28/rhAdv3 contains a hexa-histidine tag and has a molecular weight of $25 \mathrm{kDa}$. An analysis of the MS/MS data using the Mascot program and the SwissProt database showed that the highest rate (Score 2033) corresponded to a fragment of hexon of BAV-3.

The gene of the fragment of the N-terminal part of the hexon of BAV-3 was synthesized. The genetic construct pET28/rhAdv3 and the microorganism strain BL21/pET28/rhAdv3 producing rhAdv3 protein were obtained. rhAdv3 has the potential to develop test systems designed to diagnose adenoviral infection of farm animals.

Keywords: gene, cloning, microorganism strain, adenovirus, recombinant protein.

\section{INTRODUCTION}

Bovine adenovirus type 3 (BAV-3) belongs to the Mastadenovirus genus of the family Adenoviridae and is involved in respiratory and enteric infections of calves. Bovine adenovirus is considered to be one of the many causes of bovine respiratory diseases and may be the main cause of some outbreaks of other infectious diseases. The share of viral diseases of young animals accounts for 70 to $90 \%$ of the incidence of farm animals. The main causative agents of these types of disease are viruses of infectious 
rhinotracheitis, diarrhea, parainfluenza-3, respiratory syncytial viruses, adenoviruses, rota-, corona-, parvoviruses of cattle.

Diagnosis of bovine adenovirus is difficult due to the large number of symptoms. Pneumoenteritis of cattle of adenoviral etiology must be differentiated from viral diarrhea, respiratory syncytial virus, rhinotracheitis and parainfluenza-3 [1]. Various methods are used to detect the virus, such as virus isolation, in situ hybridization, enzyme immunoassay, immunofluorescence, restriction analysis, and PCR [2-6]. However, the above methods are time consuming and require expensive equipment and tissue culture systems. In this regard, the production of recombinant antigens of the virus of diagnostic value is very important.

Bovine adenovirus virions consist of 252 capsules consisting of 240 hexons, occupying the faces and edges of 20 equilateral triangular faces of the icosahedron and 12 pentones occupying the vertices of these faces. Hexon protein contains a group specific epitope common to all members of the genus Mastadenovirus, with significant preservation of the amino acid sequence [7]. Protein also carries specific determinants of adenovirus serotype [8]. The preservation of the hexon protein sequence between serotype 10 adenovirus and several types of mammalian adenoviruses was found [9].

A comparative analysis of the hexon genome of different types of adenovirus showed that in the region of the first 50 amino acids the coincidence was particularly low (less than 10\%), but then increased (approximately $45 \%$ identity by 65 amino acids). The third area, which is present in the loop 4 (Lp4), contained approximately 80 amino acids between positions 810 and 890. A significant lack of identity in Lp4 (less than 10\%), observed with multiple sequence alignment, was noted in the bovine adenovirus type 3 (BAV3) gene and serotype 10 chicken adenovirus (FAV10). The lower amino acid homologies observed in the structures of hexon suggest that external influences, especially host immune pressure, have a significant influence on the evolution of external epitopes of capsid proteins [9]. The 3-dimensional model of hexon protein described by Roberts et al. (1986), demonstrates that loops 1, 2 and 4 are located to the surface of the virus capsid. At the same time, the hexon protein regions embedded on the surface of the virus capsid are not subject to such influences and are limited by the structural requirements for interaction with the pentone subunits [10]. Here we report on the expression, purification and characterization of this recombinant protein (denoted as rhAdv).

\section{Materials and methods}

\section{Bacterial strains and plasmids}

E. coli DH5 $\alpha$ and E. coli BL21 (DE3) (Novagen, USA) were grown in LB medium. Plasmid vectors pGEM-TEasy (Promega, USA), pET28, pET32 (Novagen, USA). Monoclonal antibodies of mice against 6His-tag (Thermo Fisher, USA) and goat antibodies against mouse IgG conjugated with peroxidase (Merk, Germany). Restriction endonucleases BamHI, EcoRI, NcoI, XhoI and DNA ligase of phage T4 (Thermo Fisher, USA).

\section{Gene synthesis}

The amino acid sequence of the $\mathrm{N}$-terminal hexon fragment was obtained from the PubMed NCBI NP_046323.1 database. The selected amino acid sequence of the fragment $\mathrm{N}$-terminal portion of the bovine adenovirus hexon is codon optimized for expression in E. coli using Vector NTI programs. Oligonucleotides for gene synthesis were synthesized in the Laboratory of Organic Synthesis of the National Center for Biotechnology, Kazakhstan (Table 1). 


\begin{tabular}{|c|c|c|}
\hline № & Name & Nucleotide sequence \\
\hline 1 & Hexon 1 & $\begin{array}{l}\text { GGATCCGAATTCCCATGGAGACCGCGGGCAG } \\
\text { CATGGCGGTGATTGATCAGGCGG }\end{array}$ \\
\hline 2 & Hexon 2 & $\begin{array}{l}\text { CATAGCACGGGGTCTGGGTCGGATTGCGCAGCACGCG } \\
\text { GCCGCCCGCCTGATCAATCACCG }\end{array}$ \\
\hline 3 & Hexon 3 & $\begin{array}{l}\text { CCCAGACCCCGTGCTATGGCAGCTATGCGAAACCGAC } \\
\text { CAACGAACACGGCGGCATTACCA }\end{array}$ \\
\hline 4 & Hexon 4 & $\begin{array}{l}\text { TCGCCGGTGCGATAATATTTTTTTTCCACCTGGGTGTT } \\
\text { CGCTTTGGTAATGCCGCCGTGT }\end{array}$ \\
\hline 5 & Hexon 5 & $\begin{array}{l}\text { AAATATTATCGCACCGGCGATAACGGCAACCCGGAAA } \\
\text { CCGTGTTTTATACCGAAGAAGCG }\end{array}$ \\
\hline 6 & Hexon 6 & $\begin{array}{l}\text { ACCGCGTGCACCAGATGGGTATCCGGGGTCAGCACAT } \\
\text { CCGCTTCTTCGGTATAAAACACG }\end{array}$ \\
\hline 7 & Hexon 7 & $\begin{array}{l}\text { ATCTGGTGCACGCGGTGCCGGCGGCGGATCGCGCGAA } \\
\text { AGTGGAAGGCCTGAGCCAGCATG }\end{array}$ \\
\hline 8 & Hexon 8 & $\begin{array}{l}\text { AAGCAATCACGAAAGCCAATAAAGTTCGGGCGGTTCG } \\
\text { GCGCCGCATGCTGGCTCAGGCCT }\end{array}$ \\
\hline 9 & Hexon 9 & $\begin{array}{l}\text { TTATTGGCTTTCGTGATTGCTTTGTGGGCCTGATGTAT } \\
\text { TATAACAGCGGCGGCAATCTGG }\end{array}$ \\
\hline 10 & Hexon 10 & $\begin{array}{l}\text { GATCCACCACCGCGTTCAGCTGGCTGCTCTGGCCCGC } \\
\text { CAGAACGCCCAGATTGCCGCCGC }\end{array}$ \\
\hline 11 & Hexon 11 & $\begin{array}{l}\text { GAACGCGGTGGTGGATCTGCAGGATCGCAACACCGAA } \\
\text { CTGAGCTATCAGATGCTGCTGCA }\end{array}$ \\
\hline 12 & Hexon 12 & $\begin{array}{l}\text { AAGCTTCTCGAGTTAATGATGATGATGATGATGCAGC } \\
\text { AGCATCTGATAGC }\end{array}$ \\
\hline 13 & Hexon start & GGATCCGAATTCCCATGGAGAC \\
\hline 14 & Hexon stop & AAGCTTCTCGAGTTAATGAT \\
\hline
\end{tabular}

Gene synthesis was performed by two round PCR using polymerase Phusion (Thermo Scientific). In the first round of the reaction mixture was added all synthesized oligonucleotides at a concentration of $100 \mathrm{pmol} / \mu \mathrm{L}$ of each oligonucleotide. In the second round, the product of the first round were added Hexon start and Hexon stop oligonucleotides at a concentration of $50 \mathrm{pmol} / \mu \mathrm{L}$. The synthesized gene was cloned into the plasmid pGEM-TEsay. The primary structure of DNA was determined by Sanger method using the BigDye sets and automatic analyzers DNA ABI Prism 3100 (Applied Biosystems, USA). The synthesized gene was cloned into the plasmid pET28 and pET32 from the restriction sites NcoI and XhoI.

Transformation of $E$. coli and protein expression of the recombinant N-terminal fragment of hexon

Transformation of competent cells BL21 plasmid vectors pET-28 and pET-32 and with inserts of genes was performed by electroporation using MicroPulser (BioRad) under the following conditions: $100 \mathrm{ng}$ of plasmid per $50 \mu \mathrm{L}$ of cells, voltage $-2.5 \mathrm{kV}$; electrical capacitance - 25 microfarads, resistance - $200 \mathrm{ohm}$. Transfer time was $5.2 \mathrm{~ms}$. Transformed cells were incubated in $950 \mu \mathrm{L}$ of SOC at $37^{\circ} \mathrm{C}$ for $1 \mathrm{~h}$ under active shaking. Then, $50 \mu \mathrm{L}$ of cells were plated on LB agar with antibiotics as selection factor and grown at $+37^{\circ} \mathrm{C}$ for $16 \mathrm{~h}$. Single colonies of transformants were cultured in $50 \mathrm{~mL}$ of LB broth with an antibiotic. In the middle of the logarithmic phase growth of the bacterial mass $\left(\mathrm{OD}_{600}=0.6\right)$, an inducer, isopropyl- $\beta$-D-1-galactopyranoside (IPTG), was introduced at a final concentration of $0.1 \mathrm{mM}$ and incubated for $16 \mathrm{~h}$. Cells were harvested by centrifugation at $4^{\circ} \mathrm{C}, 6000 \mathrm{~g}$ for $7 \mathrm{~min}$. of hexon

Lyse and chromatographic purification of recombinant $\mathrm{N}$-terminal fragment 
Cell lysis was performed using an UP200S ultrasonic disintegrator at a frequency of $24 \mathrm{kHz}$ in a pulsed mode (10 pulses, $10 \mathrm{~s} /$ pulse) on ice in buffer $\mathrm{O}(20 \mathrm{mM} \mathrm{NaCl}, 20$ $\mathrm{mM}$ Hepes $\mathrm{pH}$ 7.5). Protein purification was performed by metal-chelate chromatography on $\mathrm{Ni} 2$ + ions using a HiTrap Chelating HP $1 \mathrm{~mL}$ column (GE Healthcare). The equilibration and loading of the lysate was performed according to the manufacturer's protocol. A stepwise imidazole gradient with initial buffer A $(500 \mathrm{mM}$ $\mathrm{NaCl}, 20 \mathrm{mM}$ Hepes $\mathrm{pH}$ 7.5, $20 \mathrm{mM}$ imidazole) and final buffer B (500 mM NaCl, 20 $\mathrm{mM}$ Hepes $\mathrm{pH} 7.5,500 \mathrm{mM}$ imidazole) was used to search for the eluting concentration of imidazole. A buffer $(20 \mathrm{mM}$ Tris- $\mathrm{HCl}, \mathrm{pH} 8.0$, containing $8 \mathrm{M}$ urea, $500 \mathrm{mM} \mathrm{NaCl}$, $20 \mathrm{mM}$ imidazole) was used for refolding of the antigen fused to theoridoxine. The column was washed with 10 volumes of the equilibration buffer layer $(20 \mathrm{mM}$ Tris$\mathrm{HCl}, \mathrm{pH} 8.0$, containing $8 \mathrm{M}$ urea, $500 \mathrm{mM} \mathrm{NaCl}, 20 \mathrm{mM}$ imidazole) and antigen was added. The refolded antigen was then eluted using a linear imidazole gradient (20-500 $\mathrm{mM}$ ). A liquid chromatograph for fast purification of FPLC proteins (Fast protein liquid chromatography, AKTA) was used in the work. The protein concentration in the lysate and fractions was determined by Bradford using bovine serum albumin as a standard [11]. Electrophoretic separation of proteins was performed by Laemmli [12] in a polyacrylamide gel (10\% and $12 \%)$ under denaturing conditions.

\section{Western blot}

Antigen Electrophoresis was performed in $11 \%$ polyacrylamide gel in the presence of sodium dodecyl sulfate (SDS) by the Laemmli method on the apparatus for vertical electrophoresis (BioRad, USA) [12]. Electrophoretic transfer of antigens from the gel to the nitrocellulose membrane was performed using an immunoblotting device (BioRad, United States) according to H. Towbin et al [13].

For immunochemical manifestations of specific antigens nitrocellulose membrane was first incubated in a solution of $1 \% \mathrm{BSA}$ overnight at $4^{\circ} \mathrm{C}$. Then washed three times with PBS and PBS-Tw and kept for $1.5 \mathrm{~h}$ at $37^{\circ} \mathrm{C}$ in a solution of monoclonal antibodies purified from ascites fluid, at a dilution of 1:100 in PBS-Tw. After that, the carrier was again washed and incubated in a working dilution of anti-peptide antibodies labeled with peroxidase $\left(1 \mathrm{~h}\right.$ at $\left.37^{\circ} \mathrm{C}\right)$. Next, the membrane was repeatedly washed and manifested the reaction. The substrate solution was prepared immediately before use as follows: $0.01 \mathrm{~g}$ of 4-chloro-naphthol (Sigma, USA) was dissolved in $2 \mathrm{~mL}$ of methanol, mixed with $18 \mathrm{~mL}$ of $\mathrm{PBS}(\mathrm{pH} 7.2-7.4)$ and $0.01 \mathrm{~mL}$ of $3 \%$ hydrogen peroxide was added.

\section{Tandem Mass Spectrometry (nanoLC-MS/MS).}

To avoid contamination of the samples with keratin, the workplace was cleaned up, which consisted in removing dust from the surface of the shelves and the table with a damp, clean paper napkin. To achieve the same goal, in the process of sample preparation up to the stage of trypsinolysis, special Eppendorof tubes (keratinfree) and tips with a filter were used. The resulting preparation of recombinant protein rhAdv3 was separated by electrophoresis in $11 \%$ PAAG. Two or three $1 \times 1 \mathrm{~mm}$ fragments were cut out of the stained with Coomassie gel, without going beyond the boundaries of the protein band, which were transferred to an Eppendorf keratinfree tubes. Then, $100 \mu \mathrm{L}$ of a solution of a mixture of $100 \mathrm{mM}$ ammonium bicarbonate with acetonitrile (1:1) was added and incubated for $30-40 \mathrm{~min}$ at $37^{\circ} \mathrm{C}$ to remove residual dye from gel pieces. After removing the supernatant a solution of $5 \mathrm{mM}$ DTT was added in the test tube and incubated for $10 \mathrm{~min}$ at $60^{\circ} \mathrm{C}$. After sample recovery, excess DTT was removed and 100 $\mu \mathrm{L}$ of a $100 \mathrm{mM}$ iodoacetamide solution was added to the gel pieces to alkylate cysteine residues and incubated at $37^{\circ} \mathrm{C}$ for 15 minutes. Excess reagent was removed and the gel slices were washed twice with $100 \mu \mathrm{L}$ solution of $50 \mathrm{mM}$ ammonium bicarbonate. For the final removal of iodoacetamide residues, the gel pieces were treated with two repeated cycles of dehydration with $200 \mu \mathrm{L}$ of $100 \%$ acetonitrile and saturated with 
water using $50 \mathrm{mM}$ ammonium bicarbonate. Before adding trypsin, the gel pieces were dehydrated again with acetonitrile, incubated for 3-5 min until the pieces were completely reduced, then acetonitrile was removed and incubated for another $5 \mathrm{~min}$. Then, $2 \mu \mathrm{L}$ of trypsin solution with a concentration of $100 \mathrm{ng} / \mu \mathrm{L}$ and $50 \mu \mathrm{L}$ of $50 \mathrm{mM}$ ammonium bicarbonate solution was added and incubated overnight at $37^{\circ} \mathrm{C}$. The next day, the supernatant containing the peptide mixture after trypsinolysis was transferred to another Eppendorf tube. The gel pieces were washed with $50 \mu \mathrm{L}$ of $50 \mathrm{mM}$ ammonium bicarbonate solution, incubated for 15-20 min, transferred and combined into a test tube containing the mixture of peptides of the first fraction from the previous step. The contents of the tube were dried on a vacuum concentrator at $45^{\circ} \mathrm{C}$ for $30-60 \mathrm{~min}$. After complete removal of water, the residue was dissolved in $10 \mu \mathrm{L}$ of a $0.1 \%$ solution of trifluoroacetic acid, and the peptide mixture was desalted using a Ziptip kit (MilliporeZiptipsMicro-C18, $0.2 \mu \mathrm{L}$ bed, Z720003-96EA).

The resulting mixture of tryptically hydrolyzed peptides was separated using HPLC and analyzed by MS spectrometer. LC-MS/MS conditions were as follows: used the AcclaimPepMap100 pre-column (C18 pre-column, $5 \mathrm{~mm}$ x $300 \mathrm{~mm}$; 5 particles; ThermoScientific) with HPLC pumps (DionexHPLCpump (Ultimate 3000 RSLCnanoSystem, ThermoScientific). The mixture of peptides was separated on column an AcclaimPep-MapRSLCcolumn $(15 \mathrm{~cm} \mathrm{x} 75 \mu \mathrm{m}, 2 \mathrm{~mm}$ particles; ThermoScientific) using a 75-min multistage acetonitrile gradient (buffer A: 0.1\% FA; buffer B $90 \% \mathrm{ACN} / 10 \% \mathrm{H}_{2} \mathrm{O}$ in $0.1 \% \mathrm{FA}$ ) at a flow rate of $0.3 \mu \mathrm{L} / \mathrm{min}$. Time table: 0 $\min -2 \%$ B, $10 \min -2 \%$ B, $58 \min -50 \%$ B, $59 \min -99 \%, 69 \min -99 \%, 70 \min -$ $2.0 \%, 75 \mathrm{~min}-2.0 \%$. As the transition between the module chromatography system and mass spectrometer ImpactII (Bruker) was used unmodified Captive Spray ion source in nanoBooster mode (Capillary $1300 \mathrm{~V}$, dry gas $3.0 \mathrm{l} / \mathrm{min}$, dry temperature $150^{\circ} \mathrm{C}$ ). The LC-MS/MS conditions were as follows: to obtain sample data, two of the most intense precursor ions were selected for subsequent fragmentation with a full time cycle of 3 seconds. The mass range was set within $\mathrm{m} /$ zot 150 to 2200 ion mode with positive polarity.

The Mascot software was used to search the SwissProt 2016_10 database (552,884 sequences; 197,760,918 residues). Search parameters: variable modifications, including cysteine carbamidomethylation and methionine (M) oxidation, fragment ion mass tolerance, 0.6 Da; mass tolerance of the parent ion, 1.20 Da.

\section{RESULTS}

\section{Gene synthesis of the N-terminal fragment of hexon of BAV-3.}

As a result of this work, the gene of the N-terminal fragment of hexon of BAV-3, 503 base pairs long, was synthesized. The resulting sequence included a fragment encoding 6 histidines and terminal restriction sites (Figure 1). 


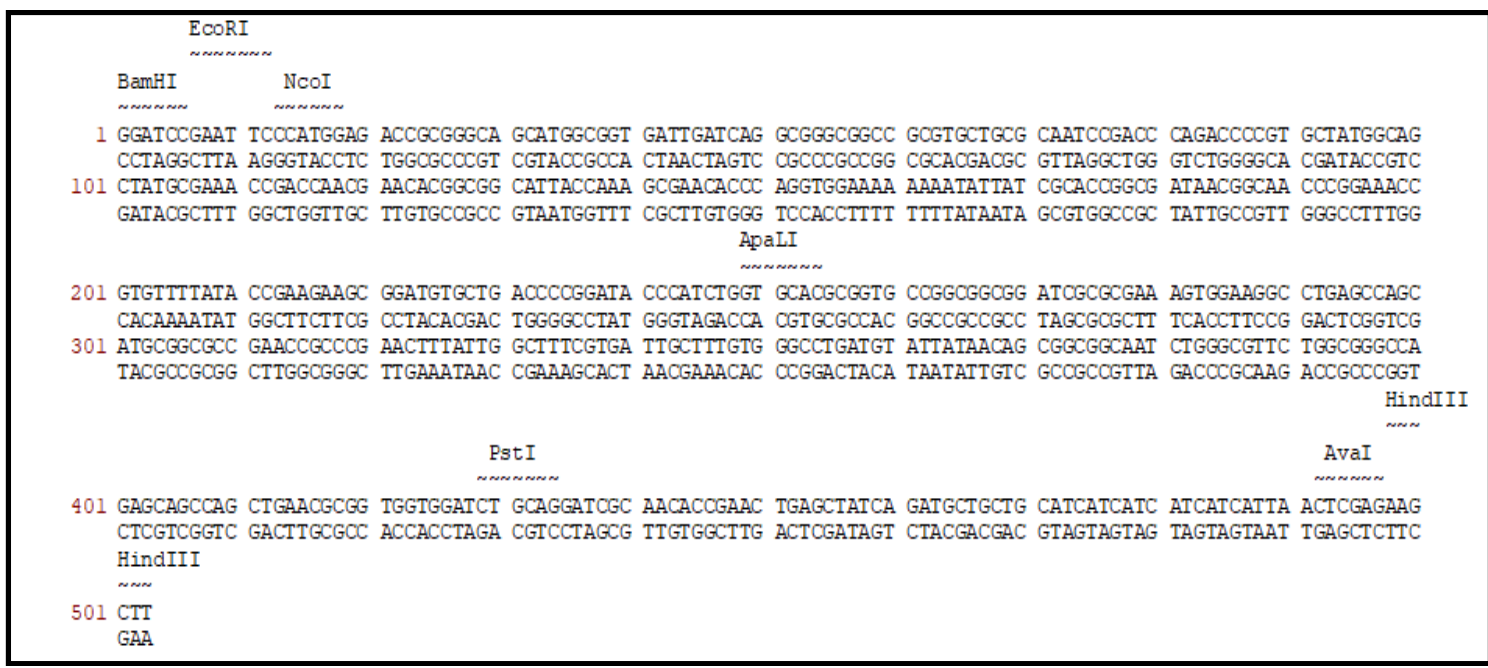

Fig. 1. The nucleotide sequence of the gene fragment designed N-terminal part of hexon

When determining the nucleotide sequence of the synthesized gene, it was revealed that 1 error was observed in the DNA sequence of the hexon fragment. The error rate was 0.9 errors $/ \mathrm{kb}$. To eliminate the error, the design and synthesis of 2 primers was carried out. After the PCR with these primers, the deletion on the gene was eliminated in accordance with figure 2. 


\begin{tabular}{|c|c|c|c|}
\hline & & & 601 \\
\hline \multirow[t]{5}{*}{ gen } & badv 3 hexon & (1) & ---------- GGAT CC GAAT TCCCAT GGAGACCGCG GGCAGCAT GG \\
\hline & LII-H1_F rc & $(601)$ & ATTCACTAGT GATTGGATCCGAATTCCCATGGAGACCGCGGGCAGCATGG \\
\hline & LII-H1_R & (95) & ATTCACTAGT GATTGGATCCGAATTCCCATGGAGACCGCGGGCAGCATGG \\
\hline & Consensüs & $(601)$ & ATTCACTAGT GATTGGATCCGAATTCCCATGGAGACCGCGGGCAGCATGG \\
\hline & & & 651 \\
\hline \multirow[t]{5}{*}{ gen } & bAdv 3 hexon & $(37)$ & CGGT GATT GATCAGGCGGGCGGCCGCGTGCTGCGCAATCCGACCCAGACO \\
\hline & LII-HI_F rC & $(651)$ & CGGT GATT GA TCAGGCGGGCGGCCGCGTGCTGCGCAAT CCGACCCA GACD \\
\hline & LII-H1_R & (145) & CGGT GATT GATCAGGCGGGCGGCCGCGTGCTGCGCAAT CCGACCCA GACC \\
\hline & Consensüs & $(651)$ & CGGT GATT GATCAGGCGGGCGGCCGCGTGCTGCGCAATCCGACCCAGACO \\
\hline & & & 701 \\
\hline \multirow[t]{5}{*}{ gen } & badv 3 hexon & $(87)$ & CCGTGCTATGGCAGCTATGCGAAACCGACCAACGAACACGGCGGCATTAC \\
\hline & $\mathrm{LII}-\mathrm{H}{ }_{1} \mathrm{~F} \mathrm{rC}$ & $(701)$ & CCGTGCTATGGCAGCTATGCGAAACCGACCAACGAACACGGCGGCATTAC \\
\hline & LII-H1_R & (195) & CCGTGCTATGGCAGCTATGCGAAACCGACCAACGAACACGGCGGCATTAC \\
\hline & Consensüs & $(701)$ & CCGTGCTATGGCAGCTATGCGAAACCGACCAACGAACACGGCGGCATTAC \\
\hline & & & 751 \\
\hline \multirow[t]{5}{*}{ gen } & badv 3 hexon & (137) & CAAAGCGAACACCCAGGTGGAAAAAAAATATTATCGCACCGGCGATAACG \\
\hline & LII-HI_F rC & (751) & CAAAGCGAACACCCAGGTGGAAAAAAAATATTATCGCACCGGCGATAACG \\
\hline & LII-H1_R & (245) & CAAAGCGAACACCCAGGTGGAAAAAAAATATTATCGCACCGGCGATAACG \\
\hline & Consensüs & (751) & CAAAGCGAACACCCAGGTGGAAAAAAAATATTATCGCACCGGCGATAACG \\
\hline & & & ( \\
\hline \multirow[t]{5}{*}{ gen } & badv 3 hexon & $(187)$ & GCAACCCGGAAACCGT GTTTTATACCGAAGAAGCGGATGT GCTGACCCCG \\
\hline & LII-HI_F rc & $(801)$ & GCAACCCGGAAACCGTGTTTTATACCGAAGAAGCGGATGTGCTGACCCCG \\
\hline & LII-H1_R & (295) & GCAACCCGGAAACCGTGTTTTATACCGAAGAAGCGGATGT GCTGACCCCG \\
\hline & Consensūs & $(801)$ & GCAACCCGGAAACCGTGTTT TATACCGAAGAAGCGGATGTGCTGACCCCG \\
\hline & & & $851 \quad 900$ \\
\hline \multirow[t]{5}{*}{ gen } & badv 3 hexon & $(237)$ & GATACCCATCTGGTGCACGCGGTGCCGGCGGCGGATCGCGCGAAAGTGGA \\
\hline & LII-HI_F rc & (851) & GATACCCATCTGGTGCACGCGGTGCCGGCGGCGGATCGCGCGAAAGTGGA \\
\hline & LII-H1_R & $(345)$ & GATACCCATCTGGTGCACGCGGTGCCGGCGGCGGAT CGCGCGAAAGTGGA \\
\hline & Consensüs & (851) & GATACCCATCTGGTGCACGCGGTGCCGGCGGCGGATCGCGCGAAAGTGGA \\
\hline & & & 901 \\
\hline \multirow[t]{5}{*}{ gen } & badv 3 hexon & $(287)$ & AGGCCTGAGCCAGCATGCGGCGCCGAACCGCCCGAACTTTATTGGCTTTC \\
\hline & LII-HI_F rC & (901) & AGGCCTGAGCCAGCATGCGGCGCCGAACCGCCCGAACTTTATTGGCTTTC \\
\hline & LII-H1_R & (395) & AGGCCTGAGCCAGCATGCGGCGCCGAACCGCCCGAACTTTATTGGCTTTC \\
\hline & Consensüs & (901) & AGGCCT GAGCCAGCATGCGGCGCCGAACCGCCCGAACT TTATTGGCTTTC \\
\hline & & & 951 \\
\hline \multirow[t]{5}{*}{ gen } & badv 3 hexon & (337) & GTGATTGCTTTGTGGGCCTGATGTATTATAACAGCGGCGGCAATCTGGGC \\
\hline & LII-H1_F rc & (951) & GTGATTGCTTTGTGGGCCTGATGTATTATAACAGCGGCGGCAATCTGGGC \\
\hline & LII-H1_R & (445) & GTGATTGCTTTGTGGGCCTGATGTATTATAACAGCGGCGGCAATCTGGGC \\
\hline & Consensüs & (951) & GTGATTGCTTTGTGGGCCTGATGTATTATAACAGCGGCGGCAATCTGGGC \\
\hline & & & 1001 \\
\hline \multirow[t]{5}{*}{ gen } & badv 3 hexon & $(387)$ & GTTCTGGCGGGCCAGAGCAGCCAGCT GAACGCGGTGGT GGATCT GCAGGA \\
\hline & LII-HI_F rC & $(1001)$ & GTTCTGGCGGGCCAGAGCAGCCAGCT GAACGCGGTGGT GGATCT GCAGGA \\
\hline & LII-H1_R & (495) & GTTCTGGCGGGCCAGAGCAGCCAGCT GAACGCGGTGGT GGATCT GCAGGA \\
\hline & Consensüs & $(1001)$ & GTTCTGGCGGGCCAGAGCAGCCAGCT GAACGCGGTGGTGGATCT GCAGGA \\
\hline & & & 1051 \\
\hline \multirow[t]{5}{*}{ gen } & badv 3 hexon & $(437)$ & TCGCAACACCGAACTGAGCTATCAGATGCTGCTGCATCATCATCATCATC \\
\hline & LII-HI_E rC & $(1051)$ & TCGCAACACCGAACTGAGCTATCAGATGCTGCTGCATCATCATCATCATC \\
\hline & $\mathrm{LII-H}{ }_{-} \_\mathrm{R}$ & $(545)$ & TCGCAACACCGAACTGAGCTATCAGATGCTGCTGCATCATCATCATCATC \\
\hline & Consensüs & $(1051)$ & TCGCAACACCGAACTGAGCTATCAGATGCTGCTGCATCATCATCATCATC \\
\hline & & & $\begin{array}{ll}1101 & 1150\end{array}$ \\
\hline \multirow[t]{4}{*}{ gen } & bAdv 3 hexon & (487) & 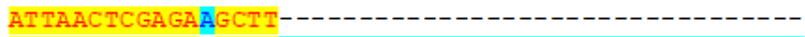 \\
\hline & LII-HI_F rc & (1101) & ATTAACTCGAGATGCTTAATCGAATTCCCGCGGCCGCCATGGCGGCCGGG \\
\hline & $\mathrm{LII-H}{ }_{-} \mathrm{R}$ & $(595)$ & ATTAACTCGAGAAGCTTAATCGAATTCCCGCGGCCGCCATGGCGGCCGGG \\
\hline & Consensus & $(1101)$ & ATTAACTCGAGAAGCT TAATCGAATTCCCGCGGCCGCCATGGCGGCCGGG \\
\hline
\end{tabular}

Fig. 2. The nucleotide sequence of the fragment synthesized N-terminal portion of hexon

The obtained gene fragment of the N-terminal part of hexon of BAV-3 was cloned into the expression plasmid pET28 by the restriction sites NcoI and XhoI. A genetic construct was obtained that carries the gene of the fragment of the N-terminal part of the hexon of BAV-3 in accordance with figure 3. 


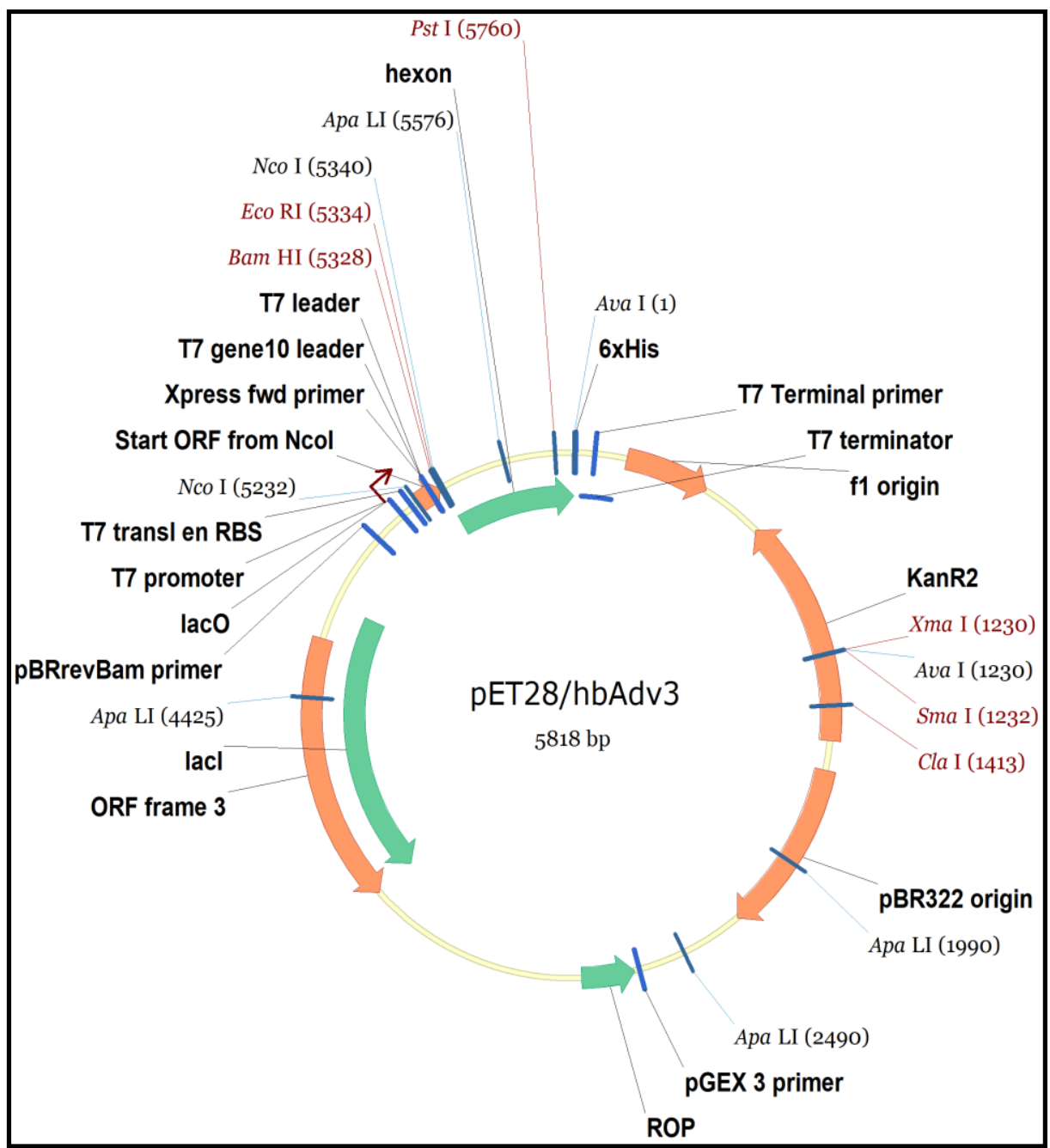

Fig. 3. Scheme of the genetic construct plasmid pET28-based gene carrier fragment N-terminal part of hexon

The transformation of genetic structures and the creation of E. coli producing rhAdv3.

The resulting genetic constructs were transformed by electroporation into expression strains E. coli BL21. Screening of colonies showed a high transformation efficiency, up to $80 \%$ of the clones carrying plasmids with hexon insert. The expression activity of the microbial strains obtained was determined. From figure 4 it is seen that the strains of microorganisms had a high expression activity.

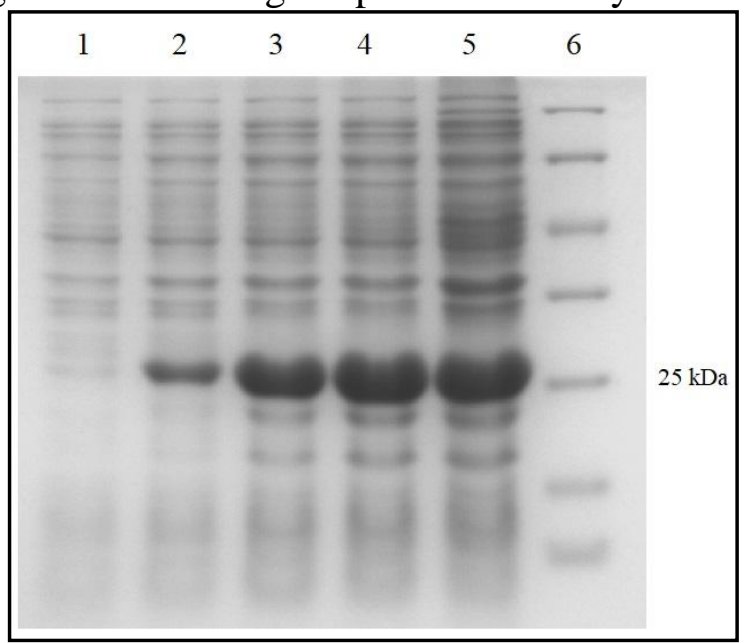

1 - cell culture without IPTG; 2 - $2 \mathrm{~h}$ of incubation with IPTG; 3 - $4 \mathrm{~h}$ of incubation with IPTG; 4 - $6 \mathrm{~h}$ with IPTG; 5 - $12 \mathrm{~h}$ with IPTG; 6 - molecular markers 
Fig. 4. PAAG electrophoresis of proteins in determining the expression activity of the producer strain BL21/pET28/rhAdv3

The strain of the microorganism E. coli BL21/pET28/rhAdv3 produced designated rhAdv3 with a molecular mass of $25 \mathrm{kDa}$. Induction of expression with $0.2 \mathrm{mM}$ IPTG after $4 \mathrm{~h}$ of incubation provided high protein concentrations.

\section{Isolation and purification of rhAdv3.}

Maximum production of recombinant proteins in the soluble fraction observed under the following culture conditions: inductor concentration of $0.2 \mathrm{mM}$, cultivation temperature after induction of expression $25^{\circ} \mathrm{C}$. Due to the fact that the recombinant protein was expressed in the inclusion body, an important stage of the research is the development of the protein refolding parameter. In determining the optimal denaturing buffer, it was found that the most effective is $8 \mathrm{M}$ urea buffer.

After purification of rhAdv using metal affinity chromatography and elution with a buffer containing $200 \mathrm{mM}$ imidazole, we used SDS-PAGE and Coomassie staining to visualize rhAdv bands (Figure 5).

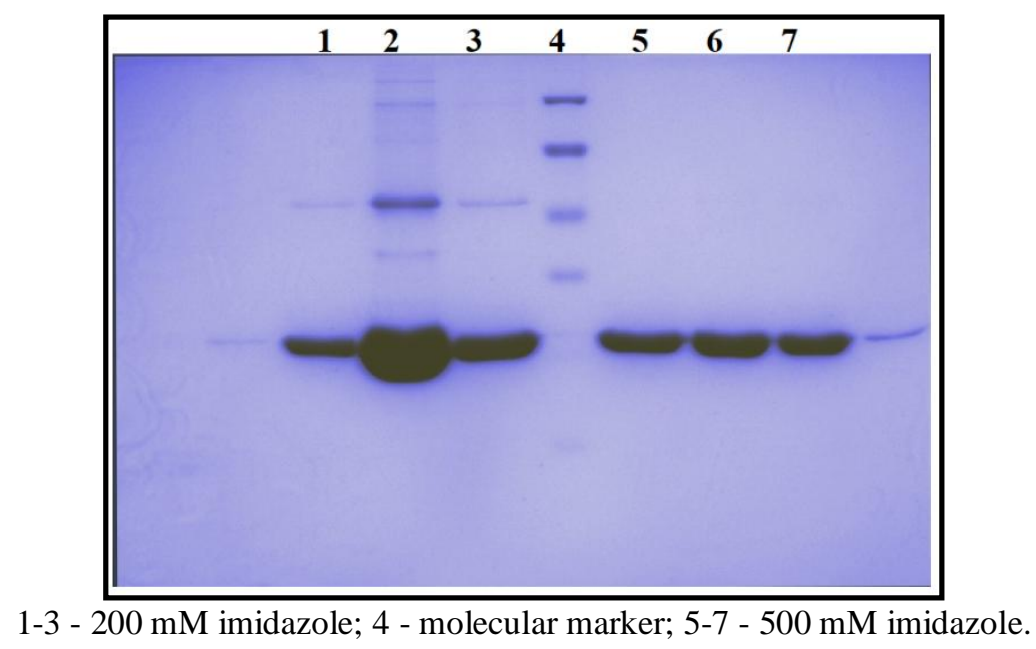

Fig. 5. PAGE of electrophoresis of proteins after chromatographic purification of rhAdv3

\section{Mass spectrometry}

For conformational identification of the rhAdv3 protein, LC-MS-MS spectrometry was used. After electrophoresis of rhAdv3 in $11 \%$ PAAG, proteolytic cleavage and chromatographic fractionation, the mass spectra of peptide peaks were obtained. For the proteolytic cleavage using trypsin, which contributed to the formation of peptides with $\mathrm{K}$ lysine moieties or arginine $\mathrm{R}$ at the $\mathrm{C}$-terminus. The obtained mass spectra formed mgf file using the program DataAnalysis. Subsequently, this file was loaded into the Mascot program, a search engine that compares the experimental data with theoretical spectra from the amino acid sequence databases of NCBI and SwissProt.

As a result, the Mascot program presented 43 of the most probable proteins corresponding to the mass spectra obtained, of which the highest rate (Score 2033) corresponded to only one hexon protein of the genus Mastadenovirus of the Adenoviridae family. The MS/MS spectra of the peptides NPTQTPCYGSYAKPTNEHGGITK, TGDNGNPETVFYTEEADVLTPDTHLVHAVPAADR of this protein with their fragmentation schemes are shown in Figure 6. 


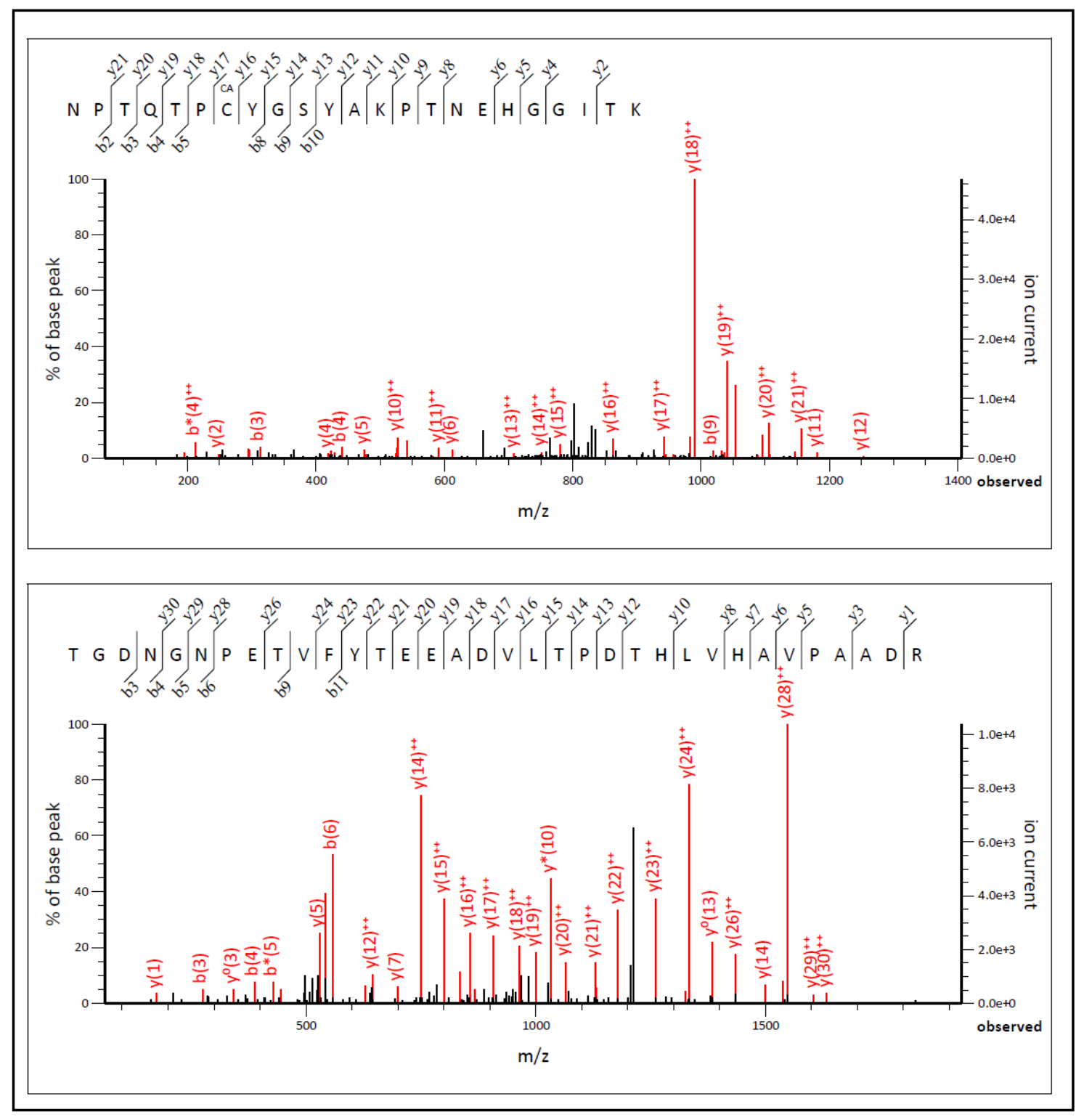

Fig. 6. MS/MS spectra of peptide peaks with fragmentation schemes for the amino acid sequences of the rhAdv3 protein

\section{DISCUSSION}

Severe infectious diseases of cattle associated with adenoviral inclusions have been reported in many countries around the world. Most often, in affected animals, various types of virus are isolated, including BAV-3 [14]. The serological levels of this infection confirm its widespread distribution. In this regard, the development of lowcost and effective test systems is an urgent problem.

The most widely used in the diagnosis of antigen is the hexon of the virus. Hexon protein consists of three identical polypeptides, forming two eight chained antiparallel beta-barrels (P1 and P2) and a triangular top. There are several highly conserved regions in the amino acid sequence of peptides, which are interrupted by loop sequences that contain variable and hypervariable regions [15].

The easiest way to obtain a DNA sequence for future protein expression is to synthesize it using PCR, using template DNA extracted from the body of interest. DNA synthesis under de novo conditions is one of the available methods for achieving this goal. This method is particularly preferred when optimization of the codon composition is necessary to achieve high-level expression in some expression systems [16]. 
As a result of the studies carried out under de novo conditions, a gene fragment of the N-terminal part of hexon of BAV-3 was synthesized. The gene was synthesized by PCR using Phusion polymerase. In the study of the nucleotide sequence of the synthesized gene, 1 deletion per 500 base pairs was detected. The error rate was 0.9 errors/kb. The deletion was corrected with primers carrying the correct nucleotide sequence in this region.

According to authors Dolgova A.S. and Stukolova O.A., (2017), the average error rate for amplification of a DNA fragment of 581 base pairs in length for Pfu and Phusion was $2.2 \pm 0.837$ and $0.6 \pm 0.548$, respectively. The data demonstrate that Phusion-Polymerase three times more efficient than Pfu polymerase in the PCR reactions of this type. Such a significant difference can be explained by the fact that only Phusion polymerase has a DNA-binding domain fused to Pyrococcus-like corrective polymerase. Using Phusion-Polymerase reduces the number of clones required to find the correct sequence of the target gene, and removes nucleotides editing step [17].

The obtained gene fragment of hexon was cloned into an expression plasmid pET28 and transformed into electrocompetent cells of E. coli strain BL21. The recombinant plasmid contained up to $80 \%$ of the colonies. Producing strain rhAdv3 expressed protein with a molecular mass of $25 \mathrm{kDa}$.

Kalaiselvi G., et al (2010) in the preparation of recombinant avian adenovirus hexon type 4 transfection efficiency was found to be $85 \%$. The authors selected colonies for ampicillin resistance. Screening of colonies was performed by the polymerase chain reaction and restriction enzyme treatment. The nucleotide sequence of the gene isolated from the producer strain showed $95 \%$ homology with other adenovirus viruses isolated in India. Recombinant clones showed a high level of expression when induced with IPTG. The molecular mass of the expressed protein was $50 \mathrm{kDa}$. The protein was a composite protein containing a polyhistidine tag from the $5^{\prime}$-end. A peptide tag was used to purify the recombinant hexon protein using a nickel-sepharose column [18].

\section{CONCLUSION}

As a result of research conducted design and synthesis of gene fragments $\mathrm{N}$ terminal part of hexon bovine adenovirus $3^{\text {rd }}$ type. The genetic construct $\mathrm{pET} 28 / \mathrm{rhAdv} 3$ and the strain of the microorganism BL21/pET28/rhAdv3 producing the rhAdv3 protein were obtained.

\section{Acknowledgements}

This research was supported by the Ministry of Education and Science Republic of Kazakhstan (STP No.BR05236307 "Creation of new drugs and innovation biotechnology for agriculture and veterinary medicine" (2018-2020), project «Development of a rapid test for serological diagnosis of bovine adenovirus type $3 »)$.

\section{REFERENCES}

1. Belak S. Ovine adenoviruses. In: Dinter Z. and Morein B. Virus infections of ruminants. Amsterdam: Elsevier Science Publishers, 1990, pp. 171-185. 
2. Giusti A., Luini M., Benkö M., Scanziani E. Pathological and situ hybridization findings in calves experimentally infected with bovine adenovirus type 4. Dtsch Tierarztl Wochenschr, 1998, vol. 105, pp. 142-144.

3. Belak S. and Thoren P. Molecular diagnosis of animals' disease: some experiences over the past decade. Expert Review of Molecular Diagnostics, 2001, Vol. 1, pp. 434-443.

4. Hoffmanna B., Beera M., Reid S.M., Mertens P., Oura C.A.L., van Rijnc P.A., Slomka M.J., Banks J., Brownd I.H., Alexander D.J., King D.P. A review of RT-PCR technologies used in veterinary virology and disease control: Sensitive and specific diagnosis of five livestock diseases notifiable to the World Organization for Animal Health. Veterinary Microbiology, 2009, vol. 139, pp. 1-23.

5. Rusvai M. and Belak S. Detection of bovine adenovirus nucleic acid sequences in nasal specimens by biotinylated DNA probes. Journal of Veterinary Medicine Series B, 1992, vol. 39, pp. 311-316.

6. Kiss I., Matiz K., Allard A., Wadell G., Benkö M. Detection of homologous DNA sequences in animal adenoviruses by polymerase chain reaction. Acta Veterinaria Hungarica, 1996, vol. 44, pp. 243-251.

7. Toogood C.I.A., Crompton J., Hay R.T. Antipeptide antisera define neutralizing epitopes on the adenovirus hexon. Journal General Virology, 1992, vol. 73, pp. 1429-1435.

8. Pettersson U., Wadell G. Antigenic structure of the adenoviruses. In: van Regenmortel M.H.V., Neurath. A.R. Immunochemistry of viruses. The basis for serodiagnosis and vaccines. Elsevier Science, 1985, pp. 295-323.

9. Sheppard M., McCoy R.J., Werner W. Genomic mapping and sequence analysis of the fowl adenovirus serotype 10 hexon gene. Journal General Virology, 1995, vol. 76, pp. 2595-2600.

10. Roberts M.M., White J.L., Grütter M.G., Burnett R.M. Three-dimensional structure of the adenovirus major coat protein hexon. Science, 1986, vol. 232, pp.11481151 .

11. Bradford M. A rapid and sensitive method for the quantitation of microgram quantitaties of protein utilizing the principle of protein - due binding. Analytical Biochemistry, 1976, vol. 72, pp. 248-254.

12. Laemmli U. K. Cleavage of structural proteins during the assembly of the head of bacteriophage T4. Nature, 1970, VOL. 227, pp. 680-685.

13. Towbin P.K., Strahelin T., Gordon J. Electrophoretic transfer of proteins from polyacrylamide gels to nitrocellulose sheets. Proceeding National Academic Science, 1979, vol. 76, pp. 4350-4354.

14. Thompson, K.G., Thomson G.W., and Henry J.N. Alimentary tract manifestations of bovine adenovirus infections. Can. Vet. J, 1981, vol. 22, pp. 68-71.

15. Dan A., Ruzsics Z., Russell W.C., Benko M., Harrach B. Analysis of the hexon gene sequence of bovine adenovirus type 4 provides further support for a new adenovirus genus (Atadenovirus). Journal of General Virology, 1998, vol. 79, pp. 14531460 .

16. Itkonen J.M., Urtti A., Bird L.E., Sarkhel S. Codon optimization and factorial screening for enhanced soluble expression of human ciliary neurotrophic factor in Escherichia coli. BMC Biotechnology, 2014, vol. 14, pp. 92-101.

17. Dolgova A.S., Stukolova O. A. High-fidelity PCR enzyme with DNA-binding domain facilitates de novo gene synthesis. 3 Biotech, 2017, Vol. 7, pp. 128-134.

18. Kalaiselvi G., Parthiban M., Narayanan M.S., Kumar S.S., Kumanan K. Rapid latex agglutination test for serodiagnosis of fowl adenovirus serotype 4 using recombinant antigen. Veterinarski arhiv, 2010, vol. 80, P.743-752. 


\section{ІРІ ҚАРАНЫН 3-ШІ ТИПТІ АДЕНОВИРУСЫ РЕКОМБИНАНТТЫ ГЕКСОНЫНЫН ШТАММ-ПРОДУЦЕНТІН АЛУ}

Мұқантаев Қ.Н., Қанаев Д.Б., Турсунов Қ.А., Тохтарова Л., Раманқұлов Е.М., Мұқанов Қ.К.

Ұлттық биотехнология ортальвы

13/5, Қорвалжын тас жолы, Нұр-Сұлтан, 010000, Қазақстан lii@biocenter.kz

\section{ТYЙІН}

Ірі қара аденовирусының диагностикасы әртүрлі аурулардың клиникалық белгілері санының көптігі мен сәйкестігіне байланысты қиындау. Вирустарды оқшаулау, in situ гибридизациясы, фермент иммуноанализі, иммунофлуоресценция, шектеуді талдау және ПТР сияқты аденовирустық инфекцияларды диагностикалау үшін әртүрлі әдістер қолданылады. Аталмыш әдістерге уақыт көп кетеді және қымбат тұратын жабдықты қажет етеді. Осыған байланысты диагностикалық маңызы бар вирустың рекомбинантты антигендеріне қол жеткізу өте маңызды болып табылады. Маңызды диагностикалық антигендердің бірі - топқа тән антиденелердің пайда болуын тудыратын вирус гексоны, топқа тән ақуыз.

De novo жағдайында 503 жұп негізінен ірі қара аденовирусы 3 типті гексонының N-терминал фрагменті гені синтезделген. BAV-3 (rhAdv3) рекомбинантты гексоннын өндіруші $E$. coli BL21/pET28/rhAdv3 штамы алынды. BL21/pET28/rhAdv3 штаммы арқылы өндірілген ақуыз гексагистидин тегіне ие және молекулалық салмағы 25 кДа болады. SwissProt дерекқорында, Mascot бағдарламасын пайдалана отырып жүргізілген эксперименттік MS/MS спектрі деректерінің талдауы көрсеткендей, ең жоғары көрсеткіш (Көрсеткіші 2033) BAV-3 гексон фрагментіне сәйкес келеді.

BAV-3 гексонының N-терминалды бөлігінің фрагмент гені синтезделді. rhAdv3 ақуызын өндіруші BL21/pET28/rhAdv3 микроорганизмінің штамы және pET28/rhAdv3 генетикалық құрамы алынды. rhAdv3-тің ауыл шаруашылығы жануарларының аденовирустық инфекциясын диагностикалауға арналған тест- жүйелерін әзірлеуге әлеуеті бар.

Негізгі сөздер: ген, клондау, микроағза штаммы, аденовирус, рекомбинантты ақуыз.

\section{ПОЛУЧЕНИЕ ШТАММА-ПРОДУЦЕНТА РЕКОМБИНАНТНОГО ГЕКСОНА БЫЧЬЕГО АДЕНОВИРУСА 3-ГО ТИПА}

Мукантаев К.Н., Турсунов К.А., Канаев Д.Б., Тохтарова Л., Раманкулов Е.М., Муканов К.К. 
Национальный иентр биотехнологии

Кургальжинское шоссе, 13/5, Нур-Султан, 010000, Казахстан

lii@biocenter.kz.

\section{АБСТРАКТ}

Диагностика бычьего аденовируса затруднена из-за большого количества и идентичности клинических симптомов различных болезней. Для диагностики аденовирусной инфекции применяют различные методы, такие как выделение вируса, гибридизация in situ, иммуноферментный анализ, иммунофлюоресценция, рестрикционный анализ и ПЦР. Данные методы занимают много времени и требуют дорогостоящего оборудования. В связи с этим, получение рекомбинантных антигенов вируса имеющих диагностическое значение является весьма актуальным. Одним из важных диагностических антигенов является гексон вируса, группоспецифический белок, индуцирующий образование группоспецифических антител.

В условиях de novo синтезирован ген $\mathrm{N}$-концевого фрагмента гексона бычьего аденовируса 3-го типа длинной 503 пар оснований. Получен штамм E. coli BL21/pET28/rhAdv3 продуцирующий рекомбинантный гексон BAV-3 (rhAdv3). Белок продуцированный штаммом BL21/pET28/rhAdv3 содержит на гекса-гистидиновую метку и имеет молекулярную массу 25 кДа. Анализ экспериментальных данных MS/MS спектров, проведенный с помощью программы Mascot по базе данных SwissProt показал, что наибольший скор (Score 2033) соответствовал фрагменту гексона BAV-3.

Синтезирован ген фрагмента N-терминальной части гексона BAV-3. Получены генетическая конструкция pET28/rhAdv3 и штамм микроорганизма BL21/pET28/rhAdv3 продуцирующий rhAdv3 белок. rhAdv3 имеет потенциал при разработке тест-систем, предназначенных для диагностики аденовирусной инфекции сельскохозяйственных животных.

Ключевые слова: ген, клонирование, штамм микроорганизма, аденовирус, рекомбинантный белок. 